\title{
Seasonal Influence of Seaweed Gel on Growth and Yield of Tomato (Solanum lycopersicum Mill.) Hybrid COTH 2
}

\author{
P. Selvakumari ${ }^{*}$ and K. Venkatesan ${ }^{2}$ \\ ${ }^{1}$ Department of Horticulture and Plantation Crops, Perambalur-621 212, Tamil Nadu, India \\ ${ }^{2}$ Post Harvest Technology Centre, TNAU, Coimbatore-641 003, Tamil Nadu, India \\ *Corresponding author
}

\begin{tabular}{|c|c|}
\hline \multicolumn{2}{|r|}{ A B S T R A C T } \\
\hline Keywords & \multirow{4}{*}{$\begin{array}{l}\text { A study has been undertaken to study the effect of seaweed gel on growth and } \\
\text { yield of tomato at College Orchard, Horticultural College and Research Institute, } \\
\text { Coimbatore. There were ten treatments including one absolute control. The trial } \\
\text { was laid out in a Randomized Block Design with three replications. The results } \\
\text { showed that treatment } \mathrm{T}_{7} \text { receiving NPK @ 200:300:200 kg ha }+ \text { O6 EM and MA } \\
\text { GEL @ } 12.5 \mathrm{~kg} \mathrm{acre}^{-1}+\mathrm{O} 6 \mathrm{EM} \text { and MA GEL } 1 \% \text { spray recorded highest plant } \\
\text { height, number of leaves, number of branches and leaf area index. Early flower } \\
\text { opening was also recorded in } \mathrm{T}_{7} \text {. Individual fruit weight, fruit yield per plant, yield } \\
\text { per plot and yield per hectare was found more in } \mathrm{T}_{7} \text { (NPK @ 200:300:200 kg ha }{ }^{-1}+ \\
\text { O6 EM and MA GEL @ } 12.5 \mathrm{~kg}^{-1} \text { acre }{ }^{-1}+\text { O6 EM and MA GEL 1\% spray). Benefit } \\
\text { Cost Ratio is also high in this treatment. }\end{array}$} \\
\hline $\begin{array}{l}\text { Solanum lycopersicum, } \\
\text { Tomato, COTH } 2, \\
\text { Seaweed gel, Effective } \\
\text { microorganism, } \\
\text { vermicompost, } \\
\text { Inorganic fertilizer, } \\
\text { Growth, Yield, Benefit } \\
\text { cost ratio. }\end{array}$ & \\
\hline Article Info & \\
\hline $\begin{array}{l}\text { Accepted: } \\
\text { 04 July } 2017 \\
\text { Available Online: } \\
\text { 10 September } 2017\end{array}$ & \\
\hline
\end{tabular}

\section{Introduction}

Tomato (Solanum lycopersicum Mill.) is one of the most widely grown vegetables in the world. The popularity of tomato among consumers has made it an important source of vitamins $\mathrm{A}$ and $\mathrm{C}$ in diets. It is popularly grown throughout India in an area of 634.4 (in $000 \mathrm{ha})$, production of $12433.2 \mathrm{in}(000 \mathrm{mt})$ and productivity of 19.6 (in $\mathrm{mt} / \mathrm{ha}$ ) (Indiastat.com, 2009-10). Inorganic fertilizers are usually quick release forms where nutrients are made rapidly available to plants. Indiscriminate use of chemical fertilizers can build up toxic concentration of salts in the soil creating chemical imbalances and environmental hazards. Seaweed extracts contain natural plant growth regulators (PGR) such as auxins and cytokinins which control the growth and structural development of plants. Application of seaweed (Ascophyllum nodosum) extract solution at one per cent to roots resulted in earlier germination and produced transplants with increased root length and shoot length compared to control in tomato (Poincelot, 1993). Application of seaweed extract (Ascophyllum nodosum) at one per cent solution increased the yield from 15.2 to $29.1 \%$ and also improved the pulp consistency and shelf life in tomato (Povolny, 1976). Heckman (1994) reported that application of ROOT PLUS at two per cent solution in the soil before transplanting increased the fresh cabbage yield by $13 \%$. 
Passam et al., (1995) reported that foliar spray of maxicrop $(50 \mathrm{ml} / \mathrm{l})$ increased the crop yield and fruit quality in cucumber. The number of fruits per plant, fruit yield per plant and per plot significantly increased with the application of $1680 \mathrm{ppm}$ seaweed extract. With this background, an attempt was made to study the effect of seaweed gel on growth and yield of tomato in College Orchard, Coimbatore.

\section{Materials and Methods}

An experiment was conducted to study the effect of seaweed gel on growth and yield of tomato (Solanum lycopersicum Mill.) hybrid COTH 2 at College Orchard, Department of Vegetable Crops, Horticultural College and Research Institute, Coimbatore.

\section{O6 EM and MA GEL}

It is a proprietary product of Bio Organic Technology (SNAP Natural and Alginate Products Ltd., Ranipet, Tamilnadu). O6 is a stabilized gel type sea algae based concentrate containing a consortium of beneficial bacteria, which acts as microbial inoculants in the soil. EM (Effective Microorganism) consists of both aerobic and anaerobic beneficial bacteria such as photosynthetic bacteria, nitrogen fixing bacteria and phosphate solubilizing bacteria. MA (Micro
Algae) is an efficient N-fixing Micro Algae, such as Chroococus turgidus. O6 EM and MA were easy to dissolve in water and drenched in the soil (or) sprayed on the foliage. Soil drenching was done at five stages viz., initial, vegetative, flowering, fruiting and harvesting stage, foliar application was also done at three stages viz., vegetative, flowering and fruiting stages as per the treatment schedule.

The experiment was laid out in red sandy loam in Randomized Block Design with ten treatment combinations replicated thrice. The plot size was $4 \mathrm{~m} \times 3 \mathrm{~m}$ and spacing followed was $60 \mathrm{~cm} \times 45 \mathrm{~cm}$. Observations on growth and yield characters were recorded at harvest. The soil was brought to fine tilth by giving four deep ploughing. At the time of last ploughing, FYM was applied at the rate of 10 $\mathrm{t} \mathrm{ha}^{-1}$. After leveling, beds were formed to accommodate the treatments. Black polythene mulch sheet of 50 gauge thickness was laid in the bed to keep the beds free of weeds to the maximum extent and to conserve the soil moisture. Paired row system of planting was followed and holes are put in two sides of the mulching sheet at a recommended spacing of $60 \times 45 \mathrm{~cm}$. Fertilizers at the rate of 200:300:200 $\mathrm{kg} \mathrm{ha}^{-1}$ were applied as urea (435 $\mathrm{kg})$, superphosphate $(1875 \mathrm{~kg}$ ) and Murate of potash $(333 \mathrm{~kg}$ ) as source of $\mathrm{N}, \mathrm{P}$ and $\mathrm{K}$ respectively.

The experiment consists of the following treatments viz.

\begin{tabular}{|c|c|}
\hline $\mathrm{T}_{1}$ & NPK @ 200:300:200 kg per ha (control) \\
\hline $\mathrm{T}_{2}$ & $\mathrm{~T}_{1}+\mathrm{O} 6 \mathrm{EM}$ and MA GEL@7.5 kg acre ${ }^{-1}$ \\
\hline $\mathrm{T}_{3}$ & $\mathrm{~T}_{1}+\mathrm{O} 6 \mathrm{EM}$ and MA GEL@10 kg acre ${ }^{-1}$ \\
\hline $\mathrm{T}_{4}$ & $\mathrm{~T}_{1}+$ O6 EM and MA GEL@12.5 kg acre \\
\hline $\mathrm{T}_{5}$ & $\mathrm{~T}_{2}+\mathrm{O} 6 \mathrm{EM}$ and MA GEL $1 \%$ spray \\
\hline $\mathrm{T}_{6}$ & $\mathrm{~T}_{3}+\mathrm{O} 6 \mathrm{EM}$ and MA GEL $1 \%$ spray \\
\hline $\mathrm{T}_{7}$ & $\mathrm{~T}_{4}+\mathrm{O} 6 \mathrm{EM}$ and MA GEL $1 \%$ spray \\
\hline $\mathrm{T}_{8}$ & Vermicompost $\left(2.5 \mathrm{t} \mathrm{ha}^{-1}\right)$ \\
\hline $\mathrm{T}_{9}$ & Vermicompost $\left(2.5 \mathrm{t} \mathrm{ha}^{-1}\right)+$ O6 EM and MA GEL@ $12.5 \mathrm{~kg} \mathrm{acre}^{-1}$ \\
\hline $\mathrm{T}_{10}$ & Vermicompost $\left(2.5 \mathrm{t} \mathrm{ha}^{-1}\right)+$ O6 EM and MA GEL@ $12.5 \mathrm{~kg} \mathrm{acre}^{-1}+$ O6 EM and MAGEL 1\% spray \\
\hline
\end{tabular}


The full dose of phosphorus and potash fertilizers and half of the dose of nitrogenous fertilizers were applied at the time of transplanting and the remaining half dose of nitrogenous fertilizer was applied 25 days after transplanting as top dressing. Drip irrigation was resorted for irrigating the field. The plants were staked with bamboo poles of one metre height at 30 days after planting to prevent lodging as the hybrid was semi determinate.

\section{Results and Discussion}

\section{Growth parameters}

\section{Plant height}

The treatment, $\mathrm{T}_{7}$ (NPK @ 200:300:200 kg $\mathrm{ha}^{-1}+$ O6 EM and MA GEL @ $12.5 \mathrm{~kg} \mathrm{acre}$ + O6 EM and MA GEL 1\% spray) produced significantly taller plants and recorded 45.54 $\mathrm{cm}, 65.2 \mathrm{~cm}$ and $93.2 \mathrm{~cm}$ of plant height on 30, 60, 90 days after planting respectively (Table 1) followed by T6 (NPK @ 200:300:200 kg ha ${ }^{-1}$ + O6 EM and MA GEL @ $10 \mathrm{~kg} \mathrm{acre}^{-1}+$ O6 EM and MA GEL 1\% spray) which recorded $40.24 \mathrm{~cm}, 62.6 \mathrm{~cm}$, $87.6 \mathrm{~cm}$ respectively. The lowest plant height was recorded in $\mathrm{T}_{1}$ (Control) with $38.5 \mathrm{~cm}, 58.5$ $\mathrm{cm}$ and $84.6 \mathrm{~cm}$ respectively at the respective stages. Similar trend was obtained in the second season also. The treatment $\mathrm{T}_{7}$ registered the higher mean value of $65.1 \mathrm{~cm}$ when compared to all the other treatments. The lowest mean value of $54.9 \mathrm{~cm}$ was recorded in $\mathrm{T}_{1}$ (Control).

Increased plant height may be due the macro and micro nutrients as well as growth promoting substances like cytokinin leading to increased growth (Zodape et al., 2011). In addition to this, auxins, IAA in particular supplied through the same seaweed gel enhanced adventitious root formation as well as better growth. Aljuburi and Almarsry (1995) attributed that auxin marginally increased Relative Growth Rate in Balady lime seedlings. In foliar sprays, an auxin containing product "ROOT PLUS" resulted in taller plants than fertilizer treatment in Broccoli (Russo et al., 1994). The plants treated with Ascophyllum nodosum showed increase in plant growth characters (Goswami, 1992). Application of seaweed extract as foliar spray enhance the growth of the plants by making the growth promoting substances available to the plants through absorption and translocation (Ramamoorthy et al., 2007).

\section{Number of branches per plant}

Number of branches per plant differed significantly among the treatments (Table 2) at all the growth stages i.e., 30, 60, 90 days after planting. Number of branches progressively increased at all stages of crop growth. Plants treated with $\left(\mathrm{T}_{7}\right)$ had significant influence on number of branches per plant and recorded more branches per plant in all the stages (6.3, 10.8 and 13.8) followed by $\left(\mathrm{T}_{6}\right)$ which recorded $5.3,10.3$ and 12.8 respectively at 30,60 and 90 days after planting. The treatment $\mathrm{T}_{1}$ (Control) recorded the lowest number of leaves per plant at all the five stages of crop growth with the values of 3.5, 8.7 and 11.9. In the second season also the treatment $\mathrm{T}_{7}$ registered the higher mean value of 9.8 when compared to all the other treatments. The lowest mean value of 7.4 was recorded in $\mathrm{T}_{1}$ (Control).

Increased number of branches was obtained with the application of seaweed gel by Heckman (1994), while increased shoot growth and total fresh weight (15-20\%) over control was observed by Gendy (1993) in tomato.

\section{Number of leaves per plant}

Number of leaves per plant differed significantly among the treatments at all the growth stages i.e., 30, 60, 90 days after 
planting. Number of leaves progressively increased at all stages of crop growth (Table 3). Plants treated with $\mathrm{T}_{7}$ had significant influence on leaf number per plant and recorded more leaf number per plant at all the stages (27.4, 59.4 and 76.9) followed by NPK (a) 200:300:200 kg ha ${ }^{-1}+$ O6 EM and MA GEL @ $10 \mathrm{~kg} \mathrm{acre}{ }^{-1}+$ O6 EM and MA GEL $1 \%$ spray) $\left(\mathrm{T}_{6}\right)$ which recorded $25.3,57.8$ and 74.8 respectively. The treatment, $\mathrm{T}_{1}$ (Control) recorded the lowest number of leaves per plant at all the three stages of crop growth with the values of 19.7, 49.3 and 67.3.

In the summer season treatment $\mathrm{T}_{7}$ registered the higher mean value of 52.4 when compared to all the other treatments. The lowest mean value of 43.5 was recorded in $\mathrm{T}_{1}$ (Control). The growth parameters were found increased at lower concentrations of seaweed extract. Similar results were recorded in Padina which induced maximum seedling growth in Cajanus cajan (Mohan et al., 1994) and Phaseolus mungo (Lingakumar et al., 2006).

\section{Leaf Area Index (LAI)}

The treatment, $\mathrm{T}_{7}$ recorded significantly higher LAI (Table 1) value (3.36) followed by the treatment, $\mathrm{T}_{6}$ which recorded 3.06. The treatment, $\mathrm{T}_{1}$ (Control) had recorded the lowest LAI (2.33) (Table 4). In the second season the treatment $\mathrm{T}_{7}$ registered the highest LAI (2.98) followed by $\mathrm{T}_{6}$ with $2.98,2.73$ respectively. The treatment $\mathrm{T}_{1}$ (control) recorded the minimum LAI of 2.18.Days to first and 50\% flowering:

The treatment, $\mathrm{T}_{7}$ recorded earliest flower opening (25.1.days) followed by the treatment, $\mathrm{T}_{6}$ which recorded 25.1 days.

The treatment, $\mathrm{T}_{1}$ (Control) had taken the longest duration (27.9 days). In the second season, treatment $\mathrm{T}_{7}$ registered the earlier flower opening (27.7 days) followed by $\mathrm{T}_{6}$ with 28.2 days. The treatment $\mathrm{T}_{1}$ (control) recorded the highest duration of 30.4 days.

Table.1 Effect of seaweed extract on plant height of tomato (Solanum lycopersicum Mill.) hybrid COTH 2

\begin{tabular}{ccccccccc} 
& \multicolumn{3}{c}{ Plant height $(\mathbf{c m})$ Kharif } & \multicolumn{3}{c}{ Plant height $(\mathbf{c m})$ Summer } \\
Treatments & 30 & 60 & 90 DAT & Mean & 30 DAT & 60 DAT & 90 DAT & Mean \\
& DAT & DAT & D0 DA & & & & \\
$\mathrm{T}_{1}$ & 38.5 & 58.5 & 84.6 & 60.5 & 31.6 & 51.6 & 81.5 & 54.9 \\
$\mathrm{~T}_{2}$ & 39.5 & 59.4 & 85.6 & 61.5 & 35.4 & 55.4 & 81.6 & 57.4 \\
$\mathrm{~T}_{3}$ & 39.8 & 61.2 & 88.6 & 63.2 & 37.2 & 57.2 & 83.2 & 59.2 \\
$\mathrm{~T}_{4}$ & 39.5 & 59.2 & 85.2 & 61.3 & 36.2 & 56.6 & 86.6 & 59.8 \\
$\mathrm{~T}_{5}$ & 38.6 & 58.6 & 87.6 & 61.6 & 34.6 & 54.6 & 84.8 & 58.0 \\
$\mathrm{~T}_{6}$ & 40.2 & 62.6 & 87.6 & 63.5 & 34.4 & 54.4 & 91.1 & 59.9 \\
$\mathrm{~T}_{7}$ & 45.5 & 65.2 & 93.2 & 67.0 & 41.6 & 61.2 & 92.6 & 65.1 \\
$\mathrm{~T}_{8}$ & 35.6 & 55.6 & 85.5 & 58.9 & 34.5 & 54.5 & 80.6 & 56.5 \\
$\mathrm{~T}_{9}$ & 38.6 & 58.2 & 89.2 & 62.0 & 34.2 & 54.2 & 84.2 & 57.5 \\
$\mathrm{~T}_{10}$ & 38.4 & 58.4 & 89.6 & 62.1 & 35.2 & 55.2 & 85.2 & 58.5 \\
$\mathrm{Grand}$ mean & 38.9 & 58.9 & 86.2 & & 35.0 & 54.7 & 84.3 & \\
$\mathrm{SEd}$ & 0.76 & 1.15 & 1.69 & & 0.68 & 1.07 & 1.65 & \\
$\mathrm{CD}(\mathrm{P}=0.05)$ & 1.60 & 2.43 & 3.56 & & 1.44 & 2.26 & 2.65 &
\end{tabular}


Table.2 Effect of seaweed extract on number of branches of tomato (Solanum lycopersicum Mill.) hybrid COTH 2

\section{Number of branches}

Treatments

Kharif

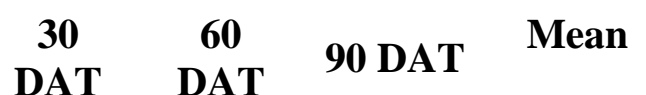

$\mathrm{T}_{1}$

$\mathrm{T}_{2} \quad 3.9$

$\mathrm{T}_{3} \quad 3.8$

$\mathrm{T}_{4} \quad 4.1$

$\mathrm{T}_{5}$

$\mathrm{T}_{6}$

$\mathrm{T}_{7}$

$\mathrm{T}_{8}$

$\mathrm{T}_{9}$

$\mathrm{T}_{10}$

Grand mean

SEd

$\mathrm{CD}(\mathrm{P}=0.05)$
8.7

8.9

8.7

9.1

4.5

5.3

6.3

5.1

6.1

4.7

4.6

0.09

0.19

10.2

10.3

10.8

10.3

9.5

10.6

9.6

0.18

0.39
11.9

11.9

11.7

12.2

13.0

12.8

13.8

11.8

12.0

12.7

12.2

0.24

0.50
8.0

8.2

8.1

8.4

9.2

9.4

10.3

9.0

9.2
Number of branches Summer

$\begin{array}{cccc}\text { 30 } & \text { 60 } & \text { 90 DAT } & \text { Mean } \\ \text { DAT } & \text { DAT } & & \\ 3.2 & 8.2 & 11.2 & 7.4 \\ 3.4 & 8.4 & 11.4 & 7.7 \\ 3.6 & 8.6 & 11.6 & 7.9 \\ 3.0 & 8.2 & 11.4 & 7.5 \\ 4.0 & 9.5 & 12.5 & 8.6 \\ 4.8 & 9.8 & 12.8 & 9.1 \\ 5.8 & 10.3 & 13.3 & 9.8 \\ 4.2 & 9.2 & 12.2 & 8.5 \\ 4.6 & 9.7 & 12.6 & 8.8 \\ 5.4 & 9.0 & 12.4 & 8.9 \\ 4.1 & 8.9 & 11.9 & \\ 0.08 & 0.17 & 0.23 & \\ 0.17 & 0.37 & 0.49 & \end{array}$

Table.3 Effect of seaweed extract on number of leaves of tomato (Solanum lycopersicum Mill.) hybrid COTH 2

Number of leaves

Treatments

$\begin{array}{cccc}\text { Treatments } & \text { 30 } & \text { 60 } & \text { 90 DA } \\ & \text { DAT } & \text { DAT } & \\ \mathrm{T}_{1} & 19.7 & 49.3 & 67.3 \\ \mathrm{~T}_{2} & 20.4 & 50.3 & 69.3 \\ \mathrm{~T}_{3} & 20.4 & 51.2 & 69.4 \\ \mathrm{~T}_{4} & 21.7 & 52.3 & 70.3 \\ \mathrm{~T}_{5} & 21.9 & 53.9 & 70.5 \\ \mathrm{~T}_{6} & 25.3 & 57.8 & 74.8 \\ \mathrm{~T}_{7} & 27.4 & 59.4 & 76.9 \\ \mathrm{~T}_{8} & 21.8 & 54.7 & 71.8 \\ \mathrm{~T}_{9} & 24.8 & 57.5 & 71.2 \\ \mathrm{~T}_{10} & 25.6 & 57.4 & 72.4 \\ \text { Grand mean } & 22.6 & 53.7 & 70.5 \\ \mathrm{SEd} & 0.44 & 1.06 & 1.38 \\ \mathrm{CD}(\mathrm{P}=0.05) & 0.94 & 2.22 & 2.91\end{array}$

Number of leaves

Summer

Mean

45.4

46.6

47.0

48.1

48.8

52.6

54.6

49.4

51.2

51.8

30 DAT

17.7

18.3

18.9

19.7

19.9

23.7

25.6

19.5

22.1

23.1

20.6

0.41

0.86
60 DAT 90 DAT

47.3

65.4

67.4

67.5

68.4

68.8

72.3

74.3

69.1

69.3

70.3

68.4

51.6

1.34

1.02

2.14
Mean

43.5

44.7

45.4

46.2

46.6

50.4

52.4

47.0

49.1

49.6 
Table.4 Effect of seaweed extract on leaf area index of tomato (Solanum lycopersicum Mill.) hybrid COTH 2

\begin{tabular}{|c|c|c|c|c|c|c|c|c|}
\hline \multirow{2}{*}{ Treatments } & \multicolumn{4}{|c|}{$\begin{array}{c}\text { Leaf area index } \\
\text { Kharif }\end{array}$} & \multicolumn{4}{|c|}{$\begin{array}{c}\text { Leaf area index } \\
\text { Summer }\end{array}$} \\
\hline & 30 DAT & $\begin{array}{c}\text { 60 } \\
\text { DAT }\end{array}$ & 90 DAT & Mean & 30 DAT & $\begin{array}{c}\text { 60 } \\
\text { DAT }\end{array}$ & $\begin{array}{c}90 \\
\text { DAT }\end{array}$ & Mean \\
\hline $\mathrm{T}_{1}$ & 1.09 & 2.47 & 3.45 & 2.33 & 1.01 & 2.27 & 3.28 & 2.18 \\
\hline $\mathrm{T}_{2}$ & 1.24 & 2.68 & 3.67 & 2.53 & 1.20 & 2.49 & 3.43 & 2.37 \\
\hline $\mathrm{T}_{3}$ & 1.42 & 2.95 & 3.98 & 2.78 & 1.39 & 2.75 & 3.78 & 2.64 \\
\hline $\mathrm{T}_{4}$ & 1.64 & 2.76 & 3.74 & 2.71 & 1.21 & 2.54 & 3.51 & 2.42 \\
\hline $\mathrm{T}_{5}$ & 1.68 & 2.84 & 3.76 & 2.76 & 1.26 & 2.60 & 3.57 & 2.47 \\
\hline $\mathrm{T}_{6}$ & 1.78 & 2.98 & 4.43 & 3.06 & 1.46 & 2.86 & 3.89 & 2.73 \\
\hline $\mathrm{T}_{7}$ & 1.98 & 3.45 & 4.65 & 3.36 & 1.64 & 2.99 & 4.32 & 2.98 \\
\hline $\mathrm{T}_{8}$ & 1.74 & 2.83 & 4.12 & 2.89 & 1.32 & 2.63 & 3.80 & 2.58 \\
\hline $\mathrm{T}_{9}$ & 1.75 & 2.93 & 4.10 & 2.91 & 1.48 & 2.84 & 3.83 & 2.71 \\
\hline $\mathrm{T}_{10}$ & 1.87 & 2.89 & 4.05 & 2.93 & 1.57 & 2.91 & 4.03 & 2.83 \\
\hline $\begin{array}{l}\text { Grand } \\
\text { Mean }\end{array}$ & 1.59 & 2.84 & 3.95 & & 1.33 & 2.65 & 3.69 & \\
\hline SEd & 0.032 & 0.056 & 0.077 & & 0.027 & 0.052 & 0.072 & \\
\hline $\begin{array}{c}\mathrm{CD}(\mathrm{p}= \\
0.05)\end{array}$ & 0.068 & 0.118 & 0.163 & & 0.057 & 0.110 & 0.152 & \\
\hline
\end{tabular}

Table.5 Effect of seaweed extract on days to first flowering and days to $50 \%$ flowering of Tomato (Solanum lycopersicum Mill.) hybrid COTH 2

\section{Treatments}

\begin{tabular}{|c|c|c|c|c|c|c|}
\hline oreatiments & Kharif & Summer & Mean & Kharif & Summer & Mean \\
\hline $\mathrm{T}_{1}$ & 27.9 & 30.4 & 29.1 & 42.3 & 44.2 & 43.3 \\
\hline $\mathrm{T}_{2}$ & 27.5 & 30.3 & 28.9 & 41.7 & 43.4 & 42.5 \\
\hline $\mathrm{T}_{3}$ & 27.6 & 30.2 & 28.8 & 39.7 & 41.4 & 40.5 \\
\hline $\mathrm{T}_{4}$ & 26.8 & 29.7 & 28.3 & 40.2 & 42.1 & 41.1 \\
\hline $\mathrm{T}_{5}$ & 27.1 & 28.9 & 28.0 & 41.9 & 43.9 & 42.9 \\
\hline $\mathrm{T}_{6}$ & 26.1 & 28.2 & 27.1 & 38.9 & 40.0 & 39.5 \\
\hline $\mathrm{T}_{7}$ & 25.1 & 27.7 & 26.4 & 36.4 & 38.4 & 37.4 \\
\hline $\mathrm{T}_{8}$ & 27.4 & 28.8 & 28.2 & 41.2 & 43.4 & 42.3 \\
\hline $\mathrm{T}_{9}$ & 26.9 & 28.1 & 27.5 & 39.8 & 40.6 & 40.2 \\
\hline $\mathrm{T}_{10}$ & 26.9 & 27.9 & 27.4 & 39.2 & 40.9 & 40.0 \\
\hline Grand mean & 26.5 & 28.6 & & 39.6 & 41.3 & \\
\hline SEd & 0.52 & 0.56 & & 0.77 & 0.81 & \\
\hline $\mathrm{CD}(\mathrm{P}=0.05)$ & 1.09 & 1.18 & & 1.63 & 1.70 & \\
\hline
\end{tabular}


Table.6 Effect of seaweed extract on individual fruit weight of tomato (Solanum lycopersicum Mill.) hybrid COTH 2

\section{Treatments}

$\begin{array}{cccc} & \text { Kharif } & \text { Summer } & \text { Mean } \\ \mathrm{T}_{1} & 49.87 & 47.63 & 48.75 \\ \mathrm{~T}_{2} & 50.63 & 48.79 & 49.71 \\ \mathrm{~T}_{3} & 50.43 & 49.87 & 50.15 \\ \mathrm{~T}_{4} & 52.34 & 50.76 & 51.55 \\ \mathrm{~T}_{5} & 53.24 & 51.28 & 52.26 \\ \mathrm{~T}_{6} & 54.34 & 52.89 & 53.61 \\ \mathrm{~T}_{7} & 55.31 & 54.98 & 55.14 \\ \mathrm{~T}_{8} & 52.39 & 50.74 & 51.56 \\ \mathrm{~T}_{9} & 53.43 & 51.26 & 52.34 \\ \mathrm{~T}_{10} & 53.54 & 52.73 & 53.13 \\ \text { and mean } & 51.86 & 50.42 & \\ \mathrm{SEd} & 1.019 & 0.990 & \end{array}$

\section{Single Fruit Weight(g)}

Table.7 Effect of seaweed extract on yield per plant of tomato (Solanum lycopersicum Mill.) hybrid COTH 2

\section{Treatments}

$\mathrm{T}_{1}$

$\mathrm{T}_{2}$

$\mathrm{T}_{3}$

$\mathrm{T}_{4}$

$\mathrm{T}_{5}$

$\mathrm{T}_{6}$

$\mathrm{T}_{7}$

$\mathrm{T}_{8}$

$\mathrm{T}_{9}$

$\mathrm{T}_{10}$

Grand mean

SEd

$\mathrm{CD}(\mathrm{P}=0.05)$
Kharif

2.09

2.11

2.30

2.31

2.35

2.49

2.74

2.34

2.38

2.48

2.44

0.048

0.101
Yield per plant (kg) Summer

2.23

2.27

2.38

2.43

2.44

2.62

2.78

2.50

2.51

2.61

2.33

0.046

0.097
Mean

2.16

2.19

2.34

2.37

2.39

2.56

2.76

2.42

2.44

2.54 
Table.8 Effect of seaweed extract on yield and their economics in tomato

$\begin{array}{ccccccc}\text { Treatments } & \begin{array}{c}\text { Yield of } \\ \text { tomato per ha } \\ \text { (kg) }\end{array} & \begin{array}{c}\text { Quantity of } \\ \text { chemicals } \\ \text { (kg)required } \\ \text { per ha }\end{array} & \begin{array}{c}\text { Cost of } \\ \text { chemical } \\ \text { required } \\ \text { per ha(Rs.) }\end{array} & \begin{array}{c}\text { Gross income } \\ \text { per hectare } \\ \text { (Rs.) }\end{array} & \begin{array}{c}\text { Net income } \\ \text { per hectare } \\ \text { (Rs.) }\end{array} & \begin{array}{c}\text { Cost benefit } \\ \text { ratio }\end{array} \\ \mathrm{T}_{1} & 67,500 & - & - & 3,37,500 & 1,80,091 & 1: 2.14 \\ \mathrm{~T}_{2} & 68,500 & 7.5 & 1162 & 3,42,500 & 1,83,929 & 1: 2.17 \\ \mathrm{~T}_{3} & 73,100 & 10 & 1550 & 3,65,500 & 2,06,541 & 1: 2.32 \\ \mathrm{~T}_{4} & 74,100 & 12.5 & 1937 & 3,70,500 & 2,11,154 & 1: 2.35 \\ \mathrm{~T}_{5} & 74,900 & 8 & 800 & 3,74,500 & 2,16,291 & 1: 2.37 \\ \mathrm{~T}_{6} & 79,800 & 10.5 & 1240 & 3,99,000 & 2,40,351 & 1: 2.53 \\ \mathrm{~T}_{7} & 86,200 & 13 & 2015 & 4,31,000 & 2,71,576 & 1: 2.73 \\ \mathrm{~T}_{8} & 75,600 & - & - & 3,78,800 & 2,21,391 & 1: 2.40 \\ \mathrm{~T}_{9} & 76,400 & 12.5 & 1937 & 3,82,000 & 2,22,654 & 1: 2.42 \\ \mathrm{~T}_{10} & 79,500 & 13 & 2015 & 3,97,500 & 2,38,076 & 1: 2.52\end{array}$

Quantity of spray solution required: 500 litres/ spray 1500 litres per hectare for 3 sprays

Quantity of seaweed gel required for drenching: $25 \mathrm{~kg}$ per hectare for 5 sprays

Rate of seaweed gel: Rs. 155/kg (Rs.0.15/g)

Cost of tomato: Rs. $5 . \mathrm{kg}$

Cost of cultivation: Rs. 1,57,409/ha

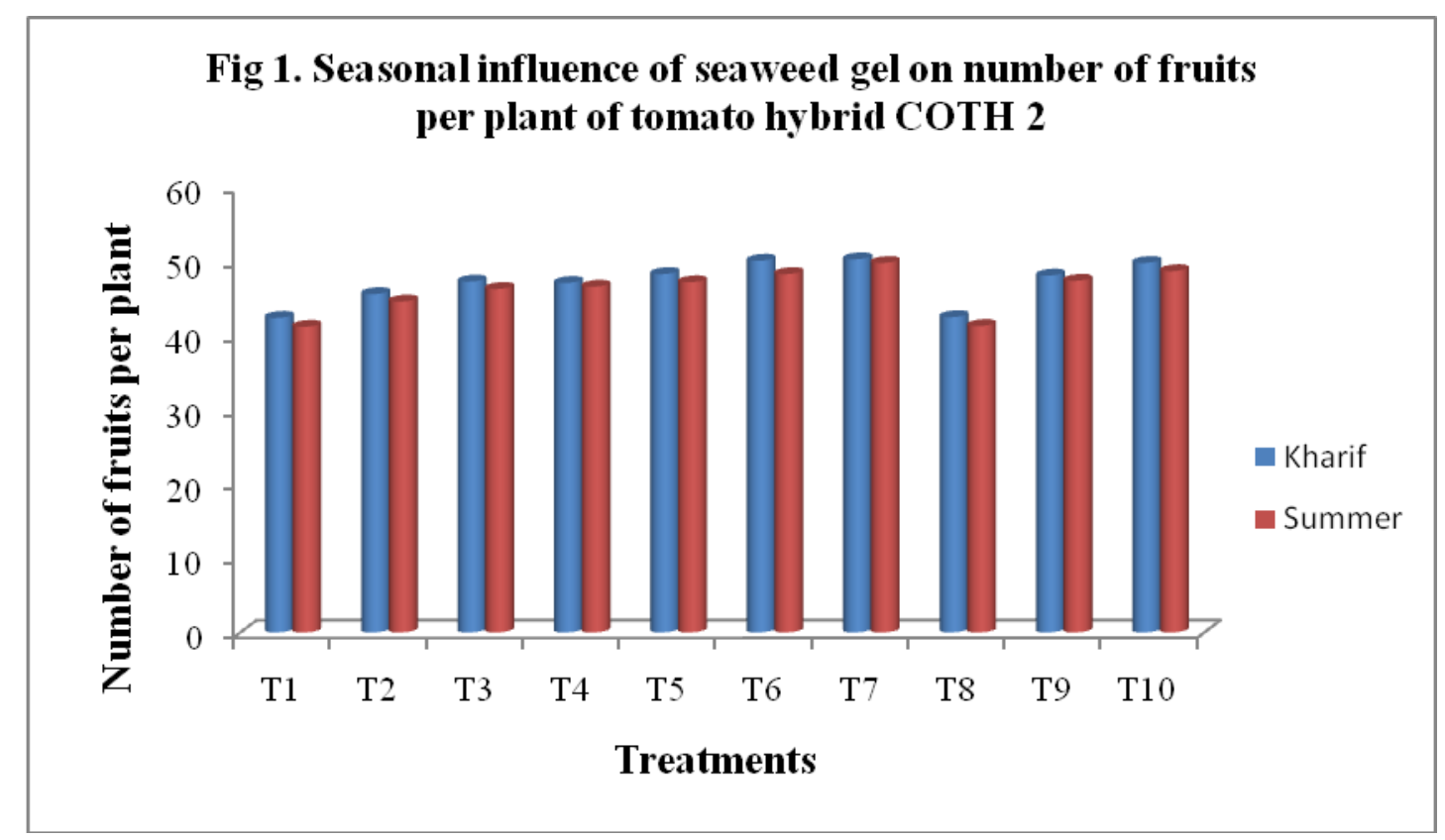

Significant differences were noted with regard to days taken for $50 \%$ flowering in the first season. The treatment, $\mathrm{T} 7$ recorded minimum days for $50 \%$ flowering (36.4 days) followed by the treatment $\mathrm{T} 6$ which recorded 38.9 days (Table 5).

The treatment, T1 (Control) had taken the longest duration for $50 \%$ flowering (42 days). The treatment $\mathrm{T} 7$ registered the earlier flower opening (38.4 days) in the second season followed by T6 with 40.0 days. The treatment T1 (control) recorded the highest duration of 44.2 days in the second season.

Increased dry matter may be due to the increased carbohydrate accumulation resulting from a more efficient photosynthetic 
activity brought about by the anatomical modifications. Nelson and Van Staden (1984) observed that application of KELPAK 60, a seaweed extract concentration increased plant dry mass in cucumber. Poincelot et al.,(1993) reported that application of 'ROOTS', a patent product containing $A$. nodsum at one per cent increased root length and shoot height compared to control in tomato plants.

Earliness is one of the important favourable phenomena since early crop fetches a premium price in the market. From the analysis of the data, it was found that the treatment comprising NPK @ 200:300:200 kg $\mathrm{ha}^{-1}+$ O6 EM and MA GEL @ $12.5 \mathrm{~kg} \mathrm{acre}^{-1}+$ O6 EM and MA GEL $1 \%$ spray $\left(\mathrm{T}_{7}\right)$ induced early flowering as compared to control in both winter and summer season.

The early flowering and fruiting in the treated plants might be due to the fact that such plants were able to build suitable carbohydrate reserves early. As far as seaweed gel is concerned, early flowering might be due to the availability of cytokinins, the accumulation of which in lateral buds would have made them more effective sink in the diversion of photoassimilates as well as other flower inducing plant hormones which ought to have ultimately resulted in better flowering and in turn yield.

There is considerable evidence that auxins act primarily in a catalytic or regulatory capacity in some plants (Chhonkar and Singh, 1959). In tomato, Sinnadurai and Amuti (1971) found that flowering increased when night temperature were cooler $\left(71-74^{0} \mathrm{~F}\right)$ though tomato is day neutral with regard to flowering under long days. Poincelot (1994) observed that application of 'ROOT PLUS' (Ascopyllum nodosum) at one per cent resulted in increased flowering and early flowering in Broccoli and Tomato.

\section{Yield parameters}

\section{Number of fruits per plant}

The number of fruits was recorded more in the treatment (50.3) $\mathrm{T}_{7}$ (NPK @ 200:300:200 kg $\mathrm{ha}^{-1}+$ O6 EM and MA GEL @ $12.5 \mathrm{~kg} \mathrm{acre}^{-1}$ + O6 EM and MA GEL 1\% spray. This was closely followed by $\mathrm{T}_{6}$ with a value of 48.3 and they are statistically on par with $\mathrm{T}_{10}$ (Fig. 1) The treatment $T_{7}$ registered the highest fruit number per plant of (49.85) followed by $\mathrm{T}_{6}$ NPK @ 200:300:200 kg ha ${ }^{-1}$ + O6 EM and MA GEL@10 kg acre ${ }^{-1}$ + O6 EM and MA GEL $1 \%$ spray with 48.3 and they are statistically on par with $\mathrm{T}_{10}$. The treatment $\mathrm{T}_{1}$ (control) recorded the minimum number of fruits per plant of 41.2 in the second season.

Highest fruit yield may be due to the most pronounced effects of seaweed extract application on development of vigorous root system, which is often expressed as higher yields due to more cytokinin synthesized and translocated to axillary buds. Increased yield may be due to increased fruit set and latter fruit weight through better canopy establishment, better inception of light and through significant reduction in inter plant competition for solar energy and nutrients. This would increase efficiency of plants to do photosynthesis and translocation of assimilates to the points of fruit set (Zodape et al., 2011). Treatment with 'ROOT PLUS' a patent compound containing seaweed extract resulted in taller plants and earlier, increased flowering and fruiting than fertilizer treatment (Poincelot, 1993). Similarly, increased fruit yield (29 per cent) was recorded by the application of seaweed extract at 1 per cent by Povolny (1976).

\section{Individual fruit weight (g)}

The fruit weight was recorded more (55.31g) in the treatment in $\mathrm{T}_{7}$ (Table 6). This was 
closely followed by $\mathrm{T}_{6}$ (NPK @ 200:300:200 $\mathrm{kg} \mathrm{ha}^{-1}+$ O6 EM and MA GEL @ $10 \mathrm{~kg}$ acre 1 + O6 EM and MA GEL 1\% spray) with a value of $54.34 \mathrm{~g}$ and they are statistically on par with $\mathrm{T}_{10}$ and $\mathrm{T}_{9}$.

The treatment $\mathrm{T}_{7}$ registered the highest fruit weight of $(54.98 \mathrm{~g})$ followed by $\mathrm{T}_{6}$ with 52.89 g. The treatment $\mathrm{T}_{1}$ (control) recorded the minimum fruit weight of $47.63 \mathrm{~g}$ in the second season.

Individual fruit weight is another component that influences yield and it was also found altered by the different treatment. Generally in tomato, the number of fruits and individual fruit weight are the major component that decide the yield and exhibit a negative relationship with one another.

Chandra and Shivaraj (1972) and Warade and Singh (1977) attributed increased weight and yield of fruit in the treated plants to the fact that they remained physiologically more active to build up sufficient food materials and reserve for developing flowers and fruits. In the presence of these substances, the plants could produce flowers early with greater fruit set, increased number of fruits with more fruit weight that ultimately led to the high yield. Similar results were found by Mote et al., (1975) and Chandra et al., (1976) in chillies.

\section{Fruit yield per plant (kg) (Table 7)}

The mean fruit yield varied from $2.09 \mathrm{~kg}$ in $\mathrm{T}_{1}$ to $2.74 \mathrm{~kg} \mathrm{plant}^{-1}$ in $\mathrm{T}_{7}$ and from $2.23 \mathrm{~kg}$ in $\mathrm{T}_{1}$ to $2.78 \mathrm{~kg} \mathrm{plant}^{-1} \mathrm{~T}_{7}$ in the first and second season respectively. In both the seasons, the treatment $\mathrm{T}_{7}$ recorded the highest yield and $\mathrm{T}_{1}$ recorded the lowest yield. Mean of two season showed that $\mathrm{T}_{7}$ recorded fruit yield per plant of $2.76 \mathrm{~kg}$ followed by the treatment $\mathrm{T}_{6}$ $(2.56 \mathrm{~kg})$ and $\mathrm{T}_{10}(2.54 \mathrm{~kg})$. In $\mathrm{T}_{9}$ and $\mathrm{T}_{10}$, addition of vermicompost released humicacid which leads to the development of more fruits per plant. The difference in concentration of chemical to influence yield could possibly be due to interaction of chemicals with the variation existed in weather parameters like light intensity, temperature etc., Increased fruit yield (29 per cent) per plant was reported with application of seaweed extract 1 per cent by Povolny (1976).

\section{Cost Benefit Ratio}

The treatment, $\mathrm{T}_{7}$ (Table 8) registered the highest benefit - cost ratio of 2.73 which was followed by $\mathrm{T}_{6}(2.53)$ and $\mathrm{T} 10$ (2.52). The lowest benefit - cost ratio was noticed in the treatment $\mathrm{T}_{1}$ (2.14).combined application of inorganic fertilizer and seaweed gel extract i.e drenching and foliar spray gave better result. It may be due to the presence of micro and macro elements present in the seaweed extract. Similar findings were also reported by Abdel Mawgoud et al., 2010.

It could be concluded that the treatment NPK @ 200:300:200 kg ha- ${ }^{-1}$ O6 EM and MA GEL@12.5 kg acre ${ }^{-1}+$ O6 EM and MA GEL $1 \%$ spray $\left(\mathrm{T}_{7}\right)$ recorded the highest net return in tomato. The combined application of inorganic fertilizers and seaweed gel significantly influenced the growth and yield of tomato hybrid COTH 2.

\section{Acknowledgement}

The financial assistance provided by M/s. Bio Organic Technology (SNAP Natural and Alginate Products Ltd., Ranipet, Tamilnadu) for conducting the present study is gratefully acknowledged.

\section{References}

Abdel Mawgoud, et al., 2010. Seaweed extract improves growth, yield and quality of different watermelon hybrids. Research Journal of Agriculture and Biological 
Science. 6(2), 161-186.

Aljuburi, H.J., and Almasry, H. 1995. Effect of interaction of salt and different concentrations of seaweed extract on Balady lime seedlings. Annals of Arid Zone. 34(2), 127-131.

Beckett, R.P., and Van Staden, J. 1990. The effect of seaweed concentrate on the yield of nutrient stressed wheat. Marine Botany. 33, 147-152.

Bohme, M., and Papadopoulos, A.P. 1999. Effect of lactate, humate and Bacillus subtilis on the growth of tomato plants in hydroponic systems. Acta Horticulturae. 481, 231-239.

Chandra, et al., 1976. Effect of NAA (planofix) on yield of chillies (Capsicum annum L.), Current Research. 5(11), 196-197.

Chandra, R., and Shivaraj, D. 1972. Influence of exogenous hormones on flowering, flower shedding and fruitset of chilli (Capsicum annum L.). Andhra Agriculture Journal. 19, 138-139.

Chhonkar, V.S., and Singh, S.N. 1959. Effect of alpha napthelene acetic acid on growth, quality and yield of tomato. (Lycopersicon esculentum Mill.). Indian Journal of Horticulture. 34(4), 435-436.

Gendy, C., 1993. Influence of nature of the culture and of algae extracts on plant growth and differentiation. Acta Horticulturae. 323, 279-287.

Goswami, B.K., 1992. Effect of Algan a product of brown algae in the management of root knot nematode, Meloidogyne incognita in brinjal. Annals of Agriculture Research. 13(4), 391-393.

Heckman, J.R., 1994. Effect of an organic biostimulant on cabbage yield. Journal of Home and Consumer Horticulture. 1, 111-113.

Johnson, S.P., 1956. Influence of growth regulators on setting of tomato fruits. American Society of Horticulture Sciences. 67, 365-367.
Lingakumar, et al., 2006. Effect of Ulva lactuca crude extract on growth and biochemical characteristics in Cyamopsis tetragonoloba L. and Phaseolus mungo L. Seaweed Research Utilization. 28 (1), 7580.

Mohan, et al., 1994. Effect of crude and commercial seaweed extracts on seed germination and seedling growth in Cajanus cajan L., Journal of Phycological Society. 33, 47-51.

Mooney, P.A., and Vanstaden M. 1986. Tentative identification of cytokinins in Sargassum heterophyllum (Phaeophyceae). Marine Botany. 30: 323-325.

Mote, et al., 1975. Effect of NAA (planofix) sprays on flower drop and yield in important varieties of chillies (Capsicum annum L.). Research Journal of Mahatma Phule Agriculture University. 6(1), 57-60.

Nelson, W. R., and Van Staden, M. 1984. The effect of seaweed concentrate on growth of nutrient stressed Greenhouse Cucumbers. Scientia Horticulture. 19(1), 81-82.

Nitsch, J. P., 1952. Plant hormones in the development of fruit quality. Biological Reviews. 27, 33-37.

Passam, B. C., and Olypois, C.M. 1995. The influence of pre and post-harvest application of seaweed extract on early production and storage of cucumber. Acta Horticulturae. 374 (Quality of Fruits and Vegetables).

Piccolo, et al., 1993. Effects of fractions of coal- derived humic substances on seed germination and growth of seedlings (Lactuca sativa and Lycopersicon esculentum). Biological Fertility of Soil. 16(1), 11-15.

Poincelot, R. P., 1993. The use of a commercial organic biostimulant for bedding plant production. Journal of Sustainable Agriculture. 3(2), 99-110. 
Poincelot, R. P., 1994. The use of a commercial organic biostimulant for field grown bedding plants. Journal of Home and Consumer Horticulture. 1(1), 95-110.

Povolny, M., 1976. Effect of seaweed extract on yield, ripening and storage of tomatoes. Sborniku VTIZZahradnictivi., 3(6):133-144.

Pramod kKumar, et al., 2000. Photosynthetic response of bell pepper to biozyme in relation to fruit yield. Vegetable Science. 27 (1), 54-56.

Ramamoorthy, et al., 2007. Utilization of seaweed extracts for enhancing yield in black gram Vigna mungo L. Hepper. Seaweed Research Utilization., 29, 97100.

Russo, et al., 1994. The use of commercial organic biostimulant for improved production of marigold cultivars. Journal of Home and Consumer Horticulture. 1(1): 83-93.

Rylski, I., 1972. Regulation of flowering in sweet pepper (Capsicum annum L.) by external application of several growth regulators. Israel Journal of Agriculture Science. 22(1), 31-40.

Sinnadurai, S.I., and Amuti, J. 1971. Regulation of flowering in onion by $\mathrm{MH}$ and CCC. Scientia Horticulturae 6(5), 486-487.

Smith, and Van Staden, 1992. The effect of tomato plants in nematode infested soil. Elsevier Science Publishers, B.V.

Warade, S.D., and Singh K. 1977. Effect of planofix on control of flower drop and fruit set in chillies (Capsicum annum). Pesticides. 11(3): 324-326.

Zodape, S.T., Gupta, A., Bhandari, S.C., Rawat, U.S., Chaudhary, D.R., Eswaran, K. and J. Chikara, 2008. Foliar application of seaweed sap as biostimulant for enhancement of yield and quality of tomato. J. Sci. Ind. Res., 70: 215-219.

\section{How to cite this article:}

Selvakumari, P. and Venkatesan, K. 2017. Seasonal Influence of Seaweed Gel on Growth and Yield of Tomato (Solanum lycopersicum Mill.) Hybrid COTH 2. Int.J.Curr.Microbiol.App.Sci. 6(9): 55-66. doi: https://doi.org/10.20546/ijcmas.2017.609.006 